Studia Kinanthropologica, XVII, 2016, (2), 105-111

The Scientific Journal for Kinanthropology

KONFIRMATIVNÍ FAKTOROVÁ ANALYZA U BOT-2 (BRUININKSOSERETSKY TEST OF MOTOR PROFICIENCY SECOND EDITION) PRO VĚKOVOU KATEGORII 4 - 7 LET

\title{
CONFIRMATORY FACTOR ANALYSIS THE BOT-2 (BRUININKS- OSERETSKY TEST OF MOTOR PROFICIENCY SECOND EDITION) FOR THE AGE GROUP 4 - 7 YEARS
}

\author{
J. Holický \& J. Jirovec
}

Univerzita Karlova, Fakulta tělesné výchovy a sportu, katedra pedagogiky, psychologie, a didaktiky TV a sportu

\begin{abstract}
The main aim of the study was to determine the suitability of diagnostic tools Bruininks-Oseretzky Test of Motor Proficiency Second Edition (BOT-2) using confirmatory factor analysis in children aged 4-7 years in the Czech Republic. The research group consisted of 88 probands aged 4-7 years. The group was made up of children from two primary schools and two kindergartens in Prague. The selectiom was held with the help of quota selection. The results of the confirmatory factor analysis BOT-2 in children in the Czech Republic were compared with the results of original artwork by Bruininks (2005). The monitored parameters were resulting index values phosphite: TLI $>0.95$, SPDC $<0.08$, CFI $>0.95$, or RMSE $<0.08$. In the original draft BOT-2 amounted the correlations between manifest variables range from 0.57 to 0.91 for the age group 4-7 years. In the Czech model was the highest correlation 0.91 (between variables "Strength \& Agility"). Fit model indicators CFI $>0.95$ and RMSE $<0.08$ was identical by original artwork and by the Czech model. The results indicated the appropriate model BOT-2 for the age group 4-7 years in the Czech Republic.
\end{abstract}

Keywords: bruininks-Oseretsky test; confimatory Factor Analysis; structural equation model

\section{SOUHRN}

Hlavním cílem této studie bylo ověrení vhodnosti diagnostického nástroje Bruininks-Oseretzky Test of Motor Proficiency, Second Edition (BOT-2) v českých podmínkách u dětí ve věku $4-7$ let pomocí konfirmativní faktorové analýzy. Výzkumný soubor tvořilo 88 probandů ve věku $4-7$ let. Skupina byla tvořena dětmi ze dvou základních škol a dvou mateřských škol v Praze, jejichž výběr proběhl kvótně. Výsledky konfirmativní faktorové analýzy BOT-2 u české populace byly porovnány s výsledky originální předlohy podle Bruininks (2005). Sledovanými parametry byly výsledné hodnoty indexů fitu: TLI $>0,95$, SRMR $<0,08$, CFI $>0,95$ nebo RMSEA $<0,08$. V originální předloze BOT-2 pro věkovou kategorii $4-7$ let dosahovala korelace mezi manifestními proměnnými rozpětí 0,57 až 0,91 . U českého modelu činila nejvyšší korelace také 0,91 (mezi proměnnými „strenght \& agility"). Fit model ukazatelů CFI $>0,95$ a RMSEA $<0,08$ byl jak u originální předlohy, tak u českého modelu totožný. $\mathrm{Z}$ výsledků byl indikován vhodný model BOT-2 pro věkovou kategorii $4-7$ let u české populace.

Klíčová slova: bruininks-Oseretsky test; konfirmativní faktorová analýza; strukturální modelování

\section{Úvod}

BOT-2 (Bruininks-Oseretsky Test of Motor Proficiency Second Edition) slouží k hodnocení vývoje motoriky. Hlavními výhodami BOT-2 jsou zejména: vysoká vypovídající hodnota, velké věkové rozpětí, možnost využití krátké formy testu a vysoká validita a reliabilita testu. Navíc je u jednotlivých subtestů BOT-2 stanovena faktorová struktura a to dokonce i pro určité věkové kategorie, což u ostatních baterií nenajdeme (Holický \& Musálek, 2013). 
BOT-2 je určen a nejvíce využíván v oblastech dětského lékařství (pediatři, fyzioterapeuti, učitelé TV s adaptivní výukou). BOT-2 je uznávaným diagnostickým nástrojem i díky tomu, že je možné jej využívat jak u běžné populace, tak i na specifických skupinách populace (Cairney et al., 2005; Deitz, Kartin, \& Kopp, 2007).

Samotný test obsahuje 53 položek, rozdělených do subtestů, zaměřených na koordinaci, přesnost a spojení různých pohybů (Wang, Long, \& Liu, 2012; Wuang, Lin, \& Su, 2009).

\section{Strukturální modelování (SEM)}

Strukturální modelování je obecným přístupem k mnohorozměrné analýze, jež se používá k prozkoumání komplexních závislostí mezi proměnnými. Rozšiřuje standardní techniky, jako jsou regresní a faktorová analýza (Urbánek, 2000).

Strukturální modelování používá dva typy proměnných (McDonald \& Marsh, 1990): manifestní proměnnou (pozorovatelná - exogenní) a latentní proměnnou (nepozorovatelná - endogenní). Důvodem, proč využíváme tuto techniku, je snaha o přezkoumání vztahů, zda se proměnné vzájemně ovlivňují předpokládaným způsobem a jak silně. Testujeme komplexní vztahy.Porovnáváme skupiny nebo provádíme analýzy longitudinálních výzkumů. Strukturální model popisuje přímé efekty exogenních proměnných na endogenní proměnnou a popisuje chybu v predikci (Muthén \& Muthén, 2012).

Modely ve strukturálním modelování (SEM) mohou být grafické a numerické. U každého modelu je nutné definovat, jaké proměnné budou jeho součástí. U proměnných manifestních je potřeba vědět, zda jsou závislé nebo nezávislé a jak kvalitně jsou měřeny. Přestože veškeré parametry modelu jsou odhadovány na základě manifestních proměnných, musíme zvolit vhodnou metodu odhadu. Nezbytnou podmínkou použitelnosti modelu je jeho identifikovatelnost (Kline, 2011).

$\mathrm{V}$ této studii jsme využili konfirmační faktorovou analýzu, která je součástí faktorové analýzy. Primárním zájmem konfirmační faktorové analýzy je ověření strukturálních hypotéz o povaze vztahů mezi manifestně a latentně proměnnými (Urbánek, 2000).

Na obrázku 1. je znázorněn obecný model konfirmační faktorové analýzy. Šipky směřují od latentně proměnné Y k manifestně proměnným X. Tento vztah nazýváme kauzálním efektem, jeho interval se pohybuje zpravidla v rozpětí -1 až 1 (Urbánek, 2000). Vztahy mezi latentně proměnnými jsou vyjádřeny úsečkami, jež mají na obou koncích šipky. Tento vztah nazýváme korelací a její interval se zpravidla nachází v rozpětí -1 až 1 (Urbánek, 2000). V současné době mezi softwary pracující s těmito modely řadíme LISREL (Jöreskog \& Sörbom, 1996), Mplus (Muthén \& Muthén, 2012) či SPSS Amos (Arbuckle, 2005).

Obrázek 1./ Figure 1.

Obecný model konfirmačni faktorové analýzy (Urbánek, 2000)./ The general model of confirmatory factor analysis (Urbanek, 2000).

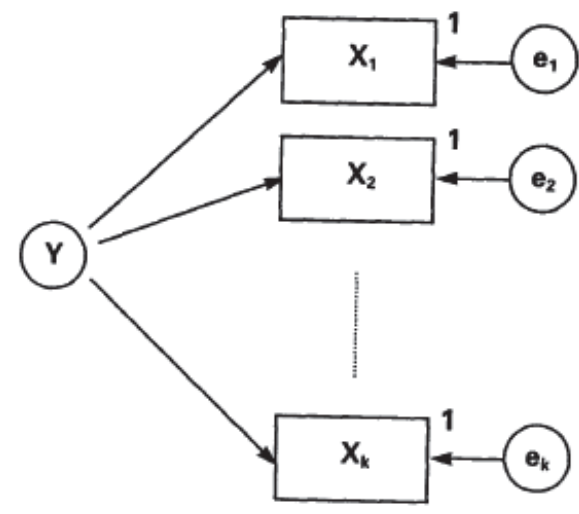

Cíl

Hlavním cílem této studie je ověření vhodnosti diagnostického nástroje Bruininks-Oseretzky Test of Motor Proficiency, Second Edition (BOT-2) v českých podmínkách u dětí ve věku 4 - 7 let pomocí konfirmativní faktorové analýzy (CFA). 


\section{Metodika}

Výzkumný soubor tvořilo 88 dětí ve věku 4 - 7 let ze dvou mateřských škol a ze dvou základních škol v Praze. Výběr škol proběhl kvótním výběrem podle doporučení Hendla (2006). Kritériem výběru bylo demografické umístění školy, zároveň se jednalo o školy bez rozšiřené výuky tělocviku a speciálních úprav v rámci vzdělávacího systému. Vedení školy a zákonní zástupci byli seznámeni s testovacím protokolem a průběhem testování a všichni podepsali informovaný souhlas k měření, které schválila etická komise Univerzity Karlovy Fakulty tělesné výchovy a sportu.

Celý výzkum se řídil předepsanými pravidly testování, popsanými v manuálu BOT-2, aby byla vypovídající hodnota testu co nejvyšší. Testování a vyhodnocování provedli pouze osoby k tomu proškolené. Byla zvolena nejkomplexnější metoda testování pomocí kompletní formy BOT-2, kdy proband absolvoval postupně dílčí úkoly na 8 stanovištích (celkem 53 úkolů).

Při ověřování vhodnosti diagnostického nástroje pomocí strukturálního modelování byla použita originální předloha SEM BOT-2 (Bruininks, 2005). Byl použit model pro věkovou kategorii 4 až 7 let, který obsahuje grafické i numerické rozhraní a hodnotící fit model. Následně jsme provedli komparaci s originální předlohou.

U grafických modelů hodnotíme výsledcích korelace mezi latentními proměnnými a kauzální vztahy mezi latentní a manifestní proměnnou.

Pro přehlednost při provádění komparace mezi originální předlohou a výsledky naší studie zůstaly názvy latentních a manifestních proměnných stejné, používáme tedy anglická, ale i česká označení. Latentní proměnné v diagramech představují: (1) „fine manual control” (jemná manuální kontrola), (2) „manual coordination” (manuální koordinace), (3) „body coordination” (tělesná koordinace), (4) „strenght \& agility” (síla a agility). Mezi manifestní proměnné patří: „FMP” (jemná motorika přesnost), „FMI” (jemná motorika - integrace), „MD” (manuální zručnost), „ULC” (horní končetiny - koordinace), „BLC” (bilaterální koordinace), „BAL” (rovnováha), „RSA” (rychlost a agility) a „STR” (síla).

Konfirmační faktorová analýza byla udělána pomocí statistického programu SPSS Amos.

Použité indexy modelu

Po formulaci a výběru modelu existuje zásadní otázka, zda je model vhodný. Platnost modelu je možno hodnotit ze dvou hledisek: (1) z hlediska shody modelu s daty získanými během měření nebo (2) vzhledem k nějakému vnějšímu kritériu.

K ověření vhodnosti modelu využíváme řady ukazatelů (Hu \& Bentler, 1998):

1. Chí-kvadrát test představuje základní a pravděpodobně nejpouživanější fit model testu. Platí zde obecné pravidlo, že čím vyšší je hodnota chí-kvadrát testu, tím horší je fit model. Hladina významnosti tohoto testu je stanovena na $\mathrm{p}>0,05$. Pokud je hodnota $\mathrm{p}$ nižší než 0,05 , je vhodnost modelu zamítnuta. Chí-kvadrát ovšem není vždy spolehlivý, nebot platí pravidlo, že čím větší je velikost souboru, tím vyšší je hodnota chí-kvadrátu a naopak (Iacobucci, 2010; McDonald \& Marsh, 1990).

2. RMSEA index označuje odmocninu z průměrného čtverce chyby odhadu (root mean square of approximation). Byl původně vytvořen Steigerem a Lindem a později pojmenován Brownem a Cudeckem (Arbuckle, 1994). Modely, které by měly být akceptovatelné, mají hodnotu indexu pod 0,08. V případě hodnot vyšších než 0,1 by měl být model zamítnut (Nevitt \& Hancock, 2000).

3. SRMR index (standard root mean square of residual) je možné vypočítat pomocí reziduální matice, odmocninu z průměru čtverce reziduí. Problém tohoto indexu spočívá v tom, že hodnota 0 sice znamená dokonalou shodu modelu s daty, ovšem není jasné, jakou hodnotu lze ještě u modelu akceptovat. Záleží mimo jiné i na počtu proměnných, použitých v modelu (Schermelleh, Moosbrugger, \& Müller, 2003; Urbánek, 2000). Modely s hodnotou do 0,08 můžeme akceptovat (Kline, 2011).

\section{Indexy založené na teorii informace}

1. Akaikeovo informační kritérium (AIC) - zde se používají hodnoty diskrepanční funkce a míra složitosti modelu. AIC měří neshodu mezi výběrovou a odhadovanou kovarianční maticí. Toto kritérium nemá žádnou škálu, slouží k porovnávání modelů. Čím menší je jeho hodnota, tím je model lepší. Rozdíl mezi modely o 10 již značí lepší model (Byrne, 2013).

2. Tucker-Lewisův index (TLI) - typický rozsah hodnot tohoto indexu leží mezi 0 a 1 , ale jeho extrémní hodnoty mohou tento interval přesahovat. Výbornou míru shody naznačují podobně jako 
u jiných indexů hodnoty blízké 1 . Doporučené hodnoty jsou alespoň 0,9 nebo nad 0,95 (Bollen, 1990; Urbánek, 2000).

3. Komparativní index shody (CFI) - Bentlerův (1992) komparativní index shody (CFI, comparative fit index) je totožný index s McDonaldovým a Marshovým indexem relativní necentrality (RNI). Na rozdíl od tohoto indexu má CFI omezené rozpětí v intervalu od 0 do 1 . Hodnoty blížící se k 1 značí dobrou shodu (Steiger, 1990; Urbánek, 2000).

\section{Výsledky}

Tabulka 1./ Table 1.

Fit model pro věkovou kategorii 4 - 7 let podle originální předlohy BOT-2 (Bruininks, 2005)./ Fit model of original draft BOT-2 for the age group 4-7 years (Bruininks, 2005).

\begin{tabular}{cccccc}
\hline Věková kategorie $4-7$ let $(\mathrm{n}=620)$ & $\chi^{2}$ & $\mathrm{df}$ & $\mathrm{p}$ & CFI & RMSEA \\
\hline Čtyřfaktorový model & 51,9 & 14 & $<0,01$ & $\star 0,97$ & $\star 0,06$ \\
\hline
\end{tabular}

Legenda. $\chi^{2}$ - hodnota chí-kvadrát testu; df - stupně volnosti; p - hladina významnosti modelu, $\star \mathrm{p}>0,05$ vhodný model; CFI - comparative fit index (komparativní index shody), $\star \mathrm{CFI}>0,95$ vhodný model; RMSEA - root mean square of approximation, $\star$ RMSEA $<0,08$ vhodný model.

Obrázek 2./ Figure 2.

Diagram čtyřfaktorového modelu pro věkovou kategorii 4 - 7 let podle originální předlohy BOT-2 (Bruininks, 2005)./ Diagram of four factor model according to the original draft BOT-2 for the age group 4-7 years (Bruininks, 2005).

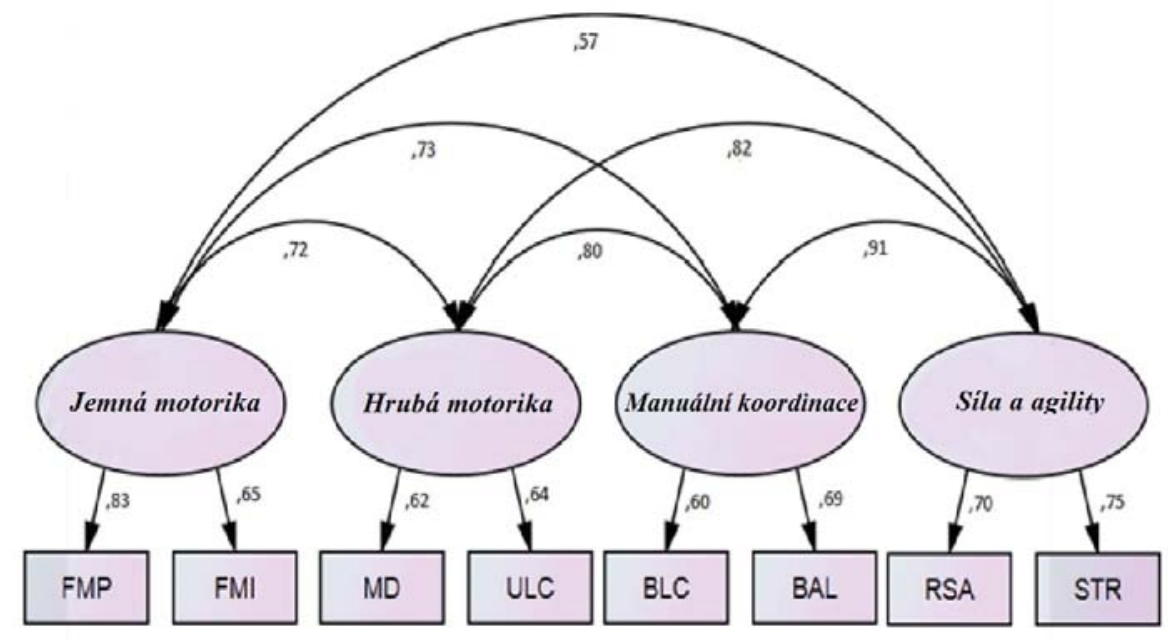

Legenda. FMP - jemná motorika přesnost, FMI - jemná motorika integrace, MD - manuální zručnost, ULC - horní končetiny koordinace, BLC - bilaterální koordinace, BAL - rovnováha, RSA - rychlost a agility, STR - síla.

Tabulka 1 a obrázek 2 představují výsledky z originální předlohy BOT-2 pro věkovou kategorii $4-7$ let. Podle výsledků diagramu fit modelu u originální předlohy (viz tabulka 1) indikujeme model jako vhodný. Pouze výsledek chí-kvadrátu $(\mathrm{p}<0,01)$ zamítá jeho vhodnost.

Diagram originální předlohy čtyřfaktorového modelu pro věkovou kategorii $4-7$ let dosahuje mezi manifestními proměnnými korelace v rozpětí 0,57 až 0,91 (viz obrázek 2). Nejvyšší mezifaktorová korelace 0,91 byla zjištěna mezi proměnnými „strenght \& agility” (síla a agility) a „body coordination” (tělesná koordinace), indikujeme tedy možnost vytvoření jednoho faktoru. Zbývající korelace se pohybovaly $\mathrm{v}$ doporučené normě. $\mathrm{V}$ případě kauzálních vztahů mezi latentními a manifestními proměnnými dosahuje model rozpětí 0,60 až 0,83 (viz obrázek 2), což odpovídá doporučené normě. 
Originální předlohu BOT-2 pro věkovou kategorii 4 - 7 let jsme srovnávali s českým modelem (viz tabulka 2 a obrázek 3).

Tabulka 2./ Table 2 .

Fit model pro věkovou kategorii 4 - 7 let u české populace./ Fit model for the age group 4-7 in the Czech population.

\begin{tabular}{ccccccccc}
\hline $\begin{array}{c}\text { Věková kategorie } 4-7 \text { let } \\
(\mathrm{n}=88)\end{array}$ & $\chi^{2}$ & $\mathrm{df}$ & $\mathrm{p}$ & $\mathrm{CFI}$ & RMSEA & TLI & SRMR & AIC \\
\hline Čtyřfaktorový model & 19,43 & 14 & $\star 0,14$ & $\star 0,98$ & $\star 0,067$ & $\star 0,97$ & $\star 0,03$ & 4108,5 \\
\hline
\end{tabular}

Legenda. $\chi^{2}$ - hodnota chí-kvadrát testu; df - stupně volnosti; p - hladina významnosti modelu, $\star \mathrm{p}>0,05$ vhodný model; CFI - comparative fit index (komparativní index shody), $\star$ CFI > 0,95 vhodný model; RMSEA - root mean square of approximation, $\star$ RMSEA $<0,08$ vhodný model; TLI - Tucker-Lewis index, «TLI > 0,95 vhodný model; SRMR - standard root mean square of residual, $\star$ SRMR $<0,08$ vhodný model; AIC - Akaike informatic criterion (Akaikeovo informační kritérium).

Obrázek 3./ Figure 3.

Diagram čtyřfaktorového modelu pro věkovou kategorii 4 - 7 let u české populace./ Diagram of fourfactor model for the age group 4-7 in the Czech population.

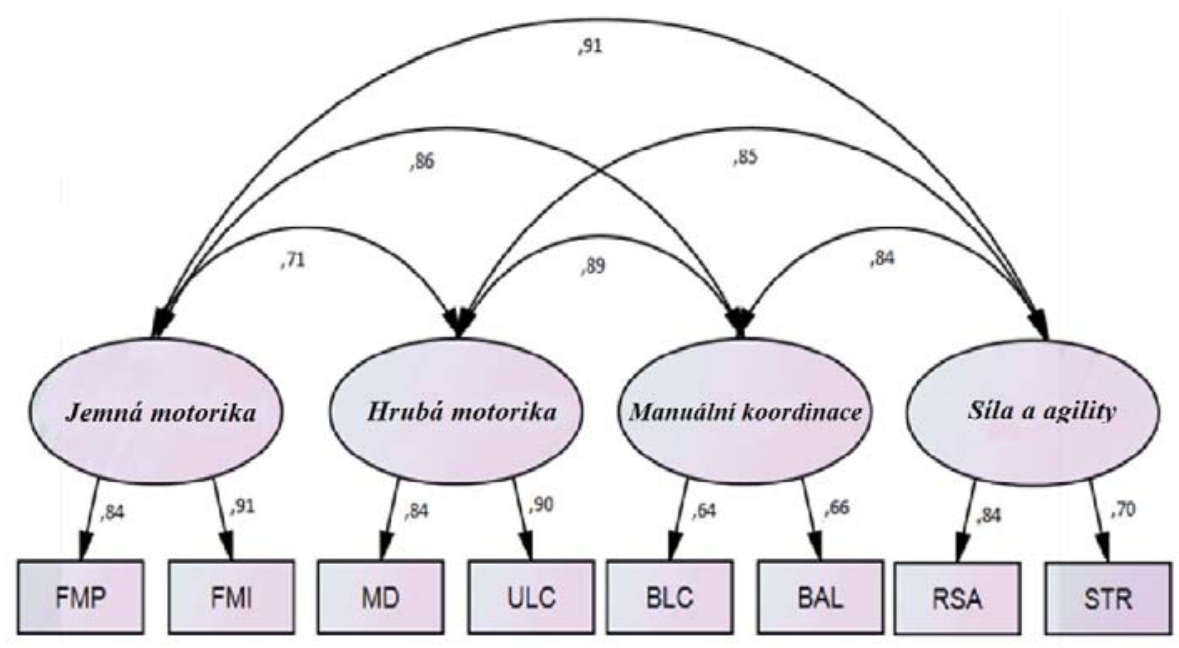

Legenda. FMP - jemná motorika přesnost, FMI - jemná motorika integrace, MD - manuální zručnost, ULC - horní končetiny koordinace, BLC - bilaterální koordinace, BAL - rovnováha, RSA - rychlost a agility, STR - síla.

Výsledky čtyřfaktorového modelu ukazují, že pro věkovou kategorii $4-7$ let indikujeme model jako vhodný. Oproti předloze byla dokonce zjištěna významnost modelu i z hlediska výsledku chí-kvadrát testu ( $\mathrm{p}>0,05)$, což však připisujeme významně nižšímu počtu probandů $(\mathrm{n}=88)$, na němž jsme strukturu BOT-2 pro věkovou kategorii $4-7$ let ověřovali. Korelace mezi faktory na obrázku 14 se pohybuje v rozpětí 0,71 až 0,91 . Její nejvyšší hodnota 0,91 byla nalezena mezi latentními proměnnými „strenght \& agility” (síla a agility) a „fine manual control” (jemná manuální kontrola). Síla vztahu potvrzuje zákonitosti ontogeneze lidské motoriky. Velikost kauzálních vztahů se nachází v rozpětí 0,64 až 0,90 (viz obrázek 3). Normalizovaná residua se pohybují v doporučeném rozpětí -2 až +2 (viz tabulka 3). 
Tabulka 3./ Table 3.

Residuální matice čtyřfaktorového modelu pro věkovou kategorii 4 - 7 let u české populace./ Residual matrices of four factor model for the age group 4-7 years in the Czech population.

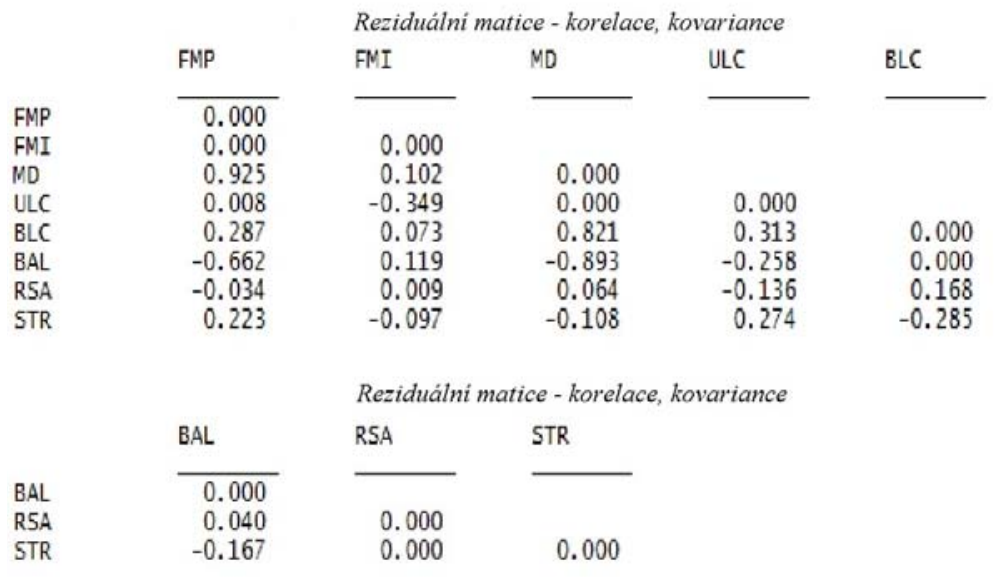

Legenda. FMP - jemná motorika přesnost, FMI - jemná motorika integrace, MD - manuální zručnost, $\mathrm{ULC}$ - horní končetiny koordinace, BLC - bilaterální koordinace, BAL - rovnováha, RSA - rychlost a agility, STR - síla.

Podle zjištěných výsledků představuje BOT-2 vhodný diagnostický nástroj pro českou populaci ve věkové kategorii $4-7$ let.

\section{Diskuze}

V naší studii jsme pomocí konfirmativní faktorové analýzy ověřovali vhodnost použití diagnostického nástroje BOT-2 v českých podmínkách. Evaluace CFA proběhla na skupině dětí (n =88) ve věku 4 - 7 let ze dvou mateřských a dvou základních škol v Praze, zapsaných v oficiálním registru MŠMT ČR. Výsledky konfirmativní faktorové analýzy u české populace byly porovnány s výsledky originální předlohy podle Bruininks (2005). Originální předloha je rozdělena do tří věkových kategorií: 4 - 7 let, 8 - 11 let a 12 - 21 let. My se zaměřili na věkovou kategorii $4-7$ let. Sledovanými parametry byly výsledné hodnoty indexů fitu: TLI $>0,95$, SRMR $<0,08$, CFI $>0,95$ nebo RMSEA $<0,08$.

V originální předloze BOT-2 pro věkovou kategorii $4-7$ let dosahovala korelace mezi manifestními proměnnými rozpětí 0,57 až 0,91 , přičemž nejvyšší hodnota byla zaznamenána mezi proměnnými „strenght \& agility” (síla a agility) a „body coordination” (tělesná koordinace). U českého modelu činila nejvyšší korelace také 0,91 , ale v tomto případě mezi proměnnými „strenght \& agility” (síla a agility) a „fine manual control” (jemná manuální kontrola). Je tedy možné, že právě oblast síly ve vývoji jedince výrazně ovlivňuje i zbývající složky psychomotorického vývoje (Gabbard, 2011). Fit model ukazatelů CFI > 0,95 a RMSEA $<0,08$ byl jak u originální předlohy, tak u českého modelu totožný. Z výsledků byl tedy indikován vhodný model BOT-2 pro věkovou kategorii $4-7$ let u české populace.

\section{Závěr}

Hlavním úkolem této studie bylo ověření vhodnosti diagnostického nástroje Bruininks-Oseretzky Test of Motor Proficiency, Second Edition (BOT-2) v českých podmínkách.

Bližší analýza výsledků pro diagnostický nástroj BOT-2 podala přesvědčivý důkaz o tom, že výstupní údaje splňují strukturální hypotézy originální předlohy. Tento diagnostický nástroj může být tudíž využit i v českých podmínkách. Při ověřování strukturálních hypotéz byla testována věková kategorie $4-7$ let podle originálního čtyřfaktorového modelu BOT-2. Konfirmativní faktorová analýza u všech věkových kategorií v české populaci vykazovala vhodný fit model (TLI > 0,95, SRMR $<0,08$, CFI > 0,95 nebo RMSEA < 0,08), a to i v případě stanovené hladiny významnosti modelu u chíkvadrátu $\mathrm{p}>0,05 .^{1}$

\footnotetext{
${ }^{1}$ Tento př́ispěvek byl realizován s podporou projektu SVV 2016-260346.
} 


\section{Literatura}

Arbuckle, J. (1994). Computer announcement amos: Analysis of moment structures. Psychometrika, $59(1), 135-137$.

Arbuckle, J. (2005). Amos 6.0 user's guide. Marketing Department: SPSS Incorporated.

Bentler, P. M. (1992). On the fit of models to covariances and methodology. Psychological Bulletin, $112(3), 400$.

Bollen, K. A. (1990). Overall fit in covariance structure models: Two types of sample size effects. Psychological Bulletin, $10^{\text {r }}(2), 256$.

Bruininks, R. H. (2005). Bruininks-Oseretsky Test of Motor Proficiency, (BOT-2). Minneapolis: Pearson Assessment.

Byrne, B. M. (2013). Structural equation modeling with AMOS: Basic concepts, applications, and programming. Routledge.

Cairney, J., Hay, J. A., Faught, B. E., Wade, T. J., Corna, L., \& Flouris, A. (2005). Developmental coordination disorder, generalized self-efficacy toward physical activity, and participation in organized and free play activities. The Journal of pediatrics, 147(4), 515-520.

Deitz, J. C., Kartin, D., \& Kopp, K. (2007). Review of the Bruininks-Oseretsky test of motor proficiency, (BOT-2). Physical \& occupational therapy in pediatrics, $27(4), 87-102$.

Gabbard, C. P. (2011). Lifelong motor development. Pearson Higher Ed.

Hendl, J. (2006). Přehled statistických metod zpracování dat: analýza a metaanalýza dat. Praha: Portál.

Holický, J., \& Musálek, M. (2013). Evaluační nástroje motoriky podle vývojových norem u české populace. Studia sportiva, 7(2), s. 103-109.

Hu, L., \& Bentler, P. M. (1998). Fit indices in covariance structure modeling: Sensitivity to underparameterized model misspecification. Psychological methods, 3(4), 424.

Iacobucci, D. (2010). Structural equations modeling: Fit indices, sample size, and advanced topics. Journal of Consumer Psychology, 20(1), 90-98.

Jöreskog, K. G., \& Sörbom, D. (1996). LISREL 8: User's reference guide: Scientific Software International.

Kline, R. B. (2011). Principles and Practice of Structural Equation Modeling. Guilford Press.

McDonald, R. P., \& Marsh, H. W. (1990). Choosing a multivariate model: Noncentrality and goodness of fit. Psychological Bulletin, $107(2), 247$.

Muthén, L. K., \& Muthén, B. O. (2012). Mplus: Statistical Analysis with Latent Variables: User's Guide. Muthén \& Muthén.

Nevitt, J., \& Hancock, G. R. (2000). Improving the root mean square error of approximation for nonnormal conditions in structural equation modeling. The Journal of experimental education, $68(3), 251-268$.

Schermelleh, K., Moosbrugger, H., \& Müller, H. (2003). Evaluating the fit of structural equation models: Tests of significance and descriptive goodness-of-fit measures. Methods of psychological research online, 8(2), 23-74.

Steiger, J. H. (1990). Structural model evaluation and modification: An interval estimation approach. Multivariate behavioral research, 25(2), 173-180.

Urbánek, T. (2000). Strukturální modelování v psychologii. Brno: Pavel Křepela.

Wang, H. Y., Long, I. M., \& Liu, M. F. (2012). Relationships between task-oriented postural control and motor ability in children and adolescents with Down syndrome. Research in Developmental Disabilities, 33(6), 1792-1798. doi: 10.1016/j.ridd.2012.05.002.

Wuang, Y. P., Lin, Y. H., \& Su, C. Y. (2009). Rasch analysis of the Bruininks-Oseretsky Test of Motor Proficiency-Second Edition in intellectual disabilities. Research in Developmental Disabilities, 30 (6), 1132-1144. doi: 10.1016/j.ridd.2009.03.003.

\section{Mgr. Jan Jirovec \\ FTVS UK \\ José Martího 269/31 \\ 162 52, Praha 6 \\ jirovec7@seznam.cz}

